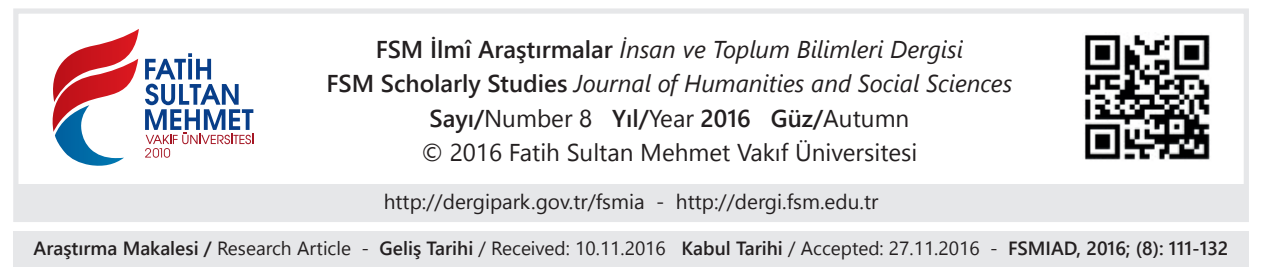

\title{
Birleşmiş Milletler Güvenlik Bölge Uygulaması
}

Naim Demirel*

\section{$\ddot{\mathbf{O} z}$}

Uluslararası toplum, uluslararası barış ve güvenliği tehdit eden uluslararası olmayan silahlı çatışmalarla son yıllarda daha sık karşılaştı. 1990'lardaki uluslararası olmayan silahlı çatışmalar dolayısıyla yüzbinlerce sivil evlerini terk etmek zorunda kaldı ve birçoğu öldü ya da yaralandı. Uluslararası toplum, böylesi durumlarda risk altındaki sivillere güvenlik ve insani yardım sunmak için bir çözüm arayışı içindedir. Bu bağlamda, uluslararası toplumun güncel çatışmaların olduğu ülkelerde insani acıları dindirmek için başvurabileceği en etkili ve elverişli tedbirlerden biri de güvenli bölgedir. Bu makale, geçmiş güvenli bölge örneklerini mercek altına almakta ve bu bölgelerin hukuki analizini içermektedir.

Anahtar Kelimeler: Güvenli bölge, uluslararası barış ve güvenlik, Birleşmiş Milletler, uluslararası olmayan silahlı çatışma, Irak, Bosna, Ruanda.

\section{Implementation of Safety Zones by the United Nations}

\section{Abstract}

The international community faced with non-international armed conflicts that threaten international peace and security in recent years more frequently. Hundreds of thousands civilians were forced to leave their homes and many of them were either killed or injured as a result of non-international armed conflicts in 1990s. The international community has been in search of a solution for such situations to provide security and humanitarian aid to civilians at risk. In this regard, safety zones may be one of the most effective measures available to the international community to alleviate human suffering in current conflict countries. The article scrutinizes past examples of safety zones and includes legal analysis of such zones.

Keywords: Safety zone, international peace and security, United Nations, non-international armed conflict, Iraq, Bosnia, Rwanda.

* Doç. Dr., Fatih Sultan Mehmet Vakıf Üniversitesi Hukuk Fakültesi, İstanbul/Türkiye, ndemirel@fsm.edu.tr 


\section{Giriş}

Birleşmiş Milletler Mülteciler Yeksek Komiserliği (BMMYK), dünyanın her yerinde mültecileri korumak, bu alanda uluslararası faaliyetleri yürütmek ve koordine etmek, mülteci sorunlarını çözmek, mültecilerin haklarını ve refahını temine çalışmak amacıyla bağımsız bir insani yardım örgütü olarak 1950 yılında kuruldu. BMMYK'nin kuruluşunun arından uzun bir süre mültecileri koruma önlemleri $\mathrm{BM}$ çerçevesinde bu organ tarafindan yürütüldü. ${ }^{1} \mathrm{Bu}$ süre içerisinde BM'nin uluslararası barış ve güvenliği korumakla görevli ana organı olan Güvenlik Konseyi, kendi müdahalesinin sivil ve tarafsız insani yardım çalışmaları için risk teşkil edeceği düşüncesiyle mültecilerin korunmasına ilişkin alanda daha çekimser kalmıştır. ${ }^{2}$

1990'dan itibaren uluslararası barış ve güvenliği, artık devletler arasındaki savaştan çok iç savaşlar, etnik çatışmalar ve terör eylemleri tehdit etmeye başladı. Bir ülkede meydana gelen silahlı çatışmaların sınır aşan etkisi gittikçe daha büyük bir alana yayıldı. Bu yeni dönemde özelikle uluslararası nitelikte olmayan silahlı çatışmalar ve kitlesel insan hakları ihlalleri, mülteci hareketliliğinin ana sebebini oluşturdu. Bu gelişmeler sonucunda artık silahlı çatışmalarda sivil halkın korunmasına ilişkin uluslararası hukukta ulaşılan standardın ortadan kalkma tehlikesi ile karşı karşıya kalınmıştır. Silahlı çatışmalardan kaynaklanan insani krizler, sadece BMMYK'nin çalışmalarıyla üstesinden gelinemeyecek hale gelmiştir. Bu sebeple 90'l1 yıllardan itibaren uluslararası alanda baş gösteren krizlerin ağır insan hakları ihlalleri, soykırım, insanlığa karşı suçlar ve savaş suçlarını içermesi, Güvenlik Konseyi’nin bu alanda etkin olmasını gerekli kılmıştır.

90'lı yılların başından bu yana uluslararası toplum birçok yöntemle uluslararası barış ve güveni korumaya çalışmaktadır. Bu bağlamda, yeni kriz döneminde silahlı çatışma bölgelerinde çatışmaların mağduru olan sivillerin korunması için mümkün olan en kapsayıcı korumayı sağlamak amacıyla güvenli bölge düşüncesi ortaya atılmıştır. Güvenli bölge oluşturmadaki hedef, genel olarak çatışma mağduru sivillere kendi ülke topraklarında güvenlik sağlamaktır. Güvenli bölge tesisi yoluyla diğer devletlere mültecilerin akın etmesi engellenerek krizin yayılmasına engel olunacaktır. ${ }^{3}$

Körfez savaş1 sırasında ABD, Kuzey Irak’ta tek taraflı olarak güvenli bölge uygulaması başlattı ve daha sonra da BM buna dahil oldu. Her ne kadar bu, BM

1 BMMYK'nin çalışmaları hakkında geniş bilgi için bkz. http://www.unhcr.org.tr/?

2 Karenfort, Jörg, Die Hilfsorganisation im bewaffneten Konflikt, Frankfurt/M., Berlin, Bern, New York, Paris, Wien 1999, s.43 vd.

3 AALCC, Summary Record of the Seminar on the "Establishment of a Safety Zone for Displaced Persons in their Country of Origin" held in New Delphi on 23 September 1994, Reports and Selected Documents, 1995, 34th Session, Annex II, 138, in: ttp://legal.un.org/ilc/documentation/english/summary_records/a_cn4_sr2494.pdf (25.03.2016) 
tarihinde güvenli bölge uygulamasının ilk örneği olarak görünse de, esas olarak Güvenlik Konseyi 1993 y1lında Bosna krizinde BM koruma bölgesi düşüncesini ele aldı. Konsey, aynı yıl içinde Sırp savaşçıların takibinden Müslüman sivil halkı korumak ve onlara insani yardımları ulaştırmak için Bosna'da altı güvenli bölge (safe area) oluşturma kararı aldı. Bundan bir yıl sonra (1994) Güvenlik Konseyi koalisyon güçlerine Ruanda da takip altındaki Hutu ve Tutsi'leri korumak için güvenli bölge (safe humanitarian zone) kurma görevi verdi. Bu yılar içinde uluslararası barış ve güvenliğin korunması amacıyla, takip altındaki sivil halkın korunması için kendi vatanında uluslararası koruma bölgesi oluşturulması düşüncesi yerleşti. ${ }^{4}$

\section{BM Çerçevesinde Güvenli Bölge Kavramının Anlamı}

Güvenli bölge karş1lı̆̆ olarak hem öğretide ve hem de uygulamada security zones, protected areas, safe havens, safe humanitarian zones ve safe areas gibi kavramlar aynı anlamda kullanılmaktadır. ${ }^{5}$ Güvenli bölge için kullanılan bu kavramlar bir bölgenin uluslararası hukuktaki statüsünü oluşturan termini technici ${ }^{6}$ değil, aksine sadece uluslararası toplum tarafından oluşturulan güvenli bölgeyi ifade etmektedir. BM, Irak krizinde güvenli bölge karş1lı̆ 1 olarak safe haven kavramını kullanmıştır. Güvenlik Konseyi'nin Bosna için güvenli bölge kararı almasından önce, çeşitli platformlarda security zones ${ }^{7}$, protected zones ${ }^{8}$ ve safe havens ${ }^{9}$ kavramları ile güvenli bölge oluşturulmasına dair görüşler dile getirildi. Ancak sonuçta BM Güvenlik Konseyi, Bosna krizinde safe areas $^{10}$ kavramını kullanmayı tercih etti. ${ }^{11}$

BM uygulamalarından hareketle güvenli bölge kavramının içeriğinin ortaya konulması, Konsey kararlarındaki farklılıklar sebebiyle birçok zorlukları içinde barındırmaktadır.

4 Simon, Anette, UN-Schutzzonen - ein Schutzinstrument für verfolgte Personen, Berlin Heidelberg, 2010, s. 18.

5 Landgren, Karin, Safety Zones and International Protection: A Dark Grey Area,: in International Journal of Refugee Law 7(3), s.436; Simon, s. 10.

6 UNHCR, The State of Worlds Refugees, 1995, s.125.

7 Dönemin Alman Dışişleri Bakanı Londra Konferansında (26.8.1992) safety zones kavramını kullanmıştır. Konuşmanın tümü için bkz. www.un.org/icty/publication/path.htm.(20.03.2016)

8 IKRK Başkanı Sommaruga ise konuşmasında protected zones, kavramını kullanmışt1, bkz. The Fall of Srebrenica, para. 45. in: http://daccess-dds-ny.un.org/doc/UNDOC/GEN/ N99/348/76/IMG/N9934876.pdf?OpenElement (15.03.2016)

9 E/CN.411992/S-1/10, 27.10.1992, para. 25 (b).

10 S/RES/819 (1993), op.para.1: " Demands that all parties and others concerned treat Srebrenica and its surroundings as a safe area which should be free from any armed attack or any other hostile act"

11 Bosna barış görüşmelerini yürüten Lord Owen'e göre "safe haven" kavramının "safe area" kavramından daha kuşatıcı olduğunu ileri sürmüştür, bkz. in: Leurdijk, Background Paper: United Nations Protected Force (UNPROFOR), in: Azimi, N., Humanitarian Action and Peace Keeping Operations, 1997, s. 77. 
Irak olayında, belirli bir bölgenin uluslararası toplum tarafindan korunmas1, bu bölgeye Irak yönetiminin girmesi ve bölge üstünde uçuşun yasaklanması konuşulmaktaydı. Ruanda'da ise sivil halkın hayatlarının korunmasına ve güvenliğinin sağlanmasına yardım etmek üzere güvenli bölgeler (secure humanitarian areas) oluşturulması ifade ediliyordu. Ancak bunun hangi sınırlar içinde ya da ne şekilde olacağına dair somut özellikler, ne görüşmelerde dile getirilmiş ve ne de ilgili kararda yer almıştır. Güvenlik Konseyi'nin Bosna kararlarında ise güvenli bölgeler, her türlü silahlı saldırılardan ve düşmanca hareketlerden uzak tutulan ve sivil halka insani yardımların ulaşmasına engel olunamayan yerler olarak ifade edilmekteydi. ${ }^{12}$ Karar görüşmeleri sırasında Fransa temsilcisi tarafından detaylı bir şekilde güvenli bölge tanımlaması yapılmıştır. Fransız temsilciye göre güvenli bölge (safe areas), BM'nin koruması altında olan, sınırları belirlenmiş; insani yardımların dağıtılması emniyet altına alınmış, her türlü şiddet eylemlerinin yasaklandığ 1 bölgedir. ${ }^{13}$ Yine güvenli bölgenin ne olduğuna ilişkin BM Genel Sekreteri’nin yaptığı tanım da önemlidir. Genel Sekreter güvenli bölgeyi, askerlerden arındırılmış, sınırları belirli olan, sivil halkın ve tarafsız askeri birliklerin, insani yardım organizasyonlarının serbestçe seyahat edebileceği yerler olarak ifade etmiştir. ${ }^{14}$

Uluslararası barış ve güvenliği sağlamak BM örgütünün ana hedeflerinden biri olmasına rağmen, BM Sözleşmesinde güvenli bölge kavramı yer almamaktadır. Her ne kadar bu kavram , 90'lı yılların başından itibaren BM Güvenlik Konseyi kararlarında yer almış ise de, BM tarihinde ilk defa 1998 yılında resmi bir otorite tarafından kullanılmıştır. BM Genel Sekreteri 1998 yılındaki raporunda silahlı çatışma bölgelerinde insani yardımların sağlanabilmesi için başka önlemlerin arasında güvenli bölgeyi de saymıştır. ${ }^{15}$ Yine BM Genel Sekreteri, 1999 yılında sunduğu raporda Güvenlik Konseyi’ne soykırım, insanlığa karşı suçlar ve savaş suçlarını içinde barındıran silahlı çatışmalarda, sivil halkın korunması ve yardım malzemelerinin ulaştırılması için, geçici güvenli bölge oluşturmayı tavsiye etmiştir. ${ }^{16}$ Burada BM Genel Sekreteri’nin güvenli bölge uygulamasını ancak belirtilen durumlarda başvurulabilecek bir tedbir olarak sınırlandırdığı anlaşılmaktadır. BM Genel Sekreteri'nin raporlarında güvenli bölge ihdas edilmesi için açık şartlar ortaya konulmakla beraber, güvenli bölgede hangi hukuk kuralının geçerli olacağı, sorumluluk ve görevin ne şekilde dağıtılacağına dair somut bilgi bulunmamaktadır.

12 S/RES/819 (1993); S/RES/824 (1993).

$13 \mathrm{~S} / 5125800,19.5 .1993,2$.

14 UNSG-Report, S/1994/555, 9.5.1994, para. 18, UNSG-Report, S/1994/1389, 1.12.1994, para. $45 \mathrm{H}$.

15 UNSG-Report, S/1998/883, 2.9.1998, para. $22 \mathrm{H}$.

16 UNSG-Report, 5/1999/957,8.9.1999, para. 39. 


\section{BM Güvenlik Konseyi Kararlarında Güvenli Bölge Uygulamaları}

\subsection{Irak’ta Kurulan Güvenli Bölge}

İkinci Körfez Savaşı'nda Irak ordusunun koalisyon birlikleri tarafindan Mart 1991'de yenilmesinden sonra, Kuzey Irak'ta Kürt azınlık grupları merkezi otoriteye başkaldırdılar. Kürt gruplarının başkaldırısı, Irak Hükümeti tarafından bastırıldı. Ardından da merkezi hükümetin ordu birlikleri Kuzey Irak’ta yaşayan Kürk azınlığa saldırdı ve Kürt sivil halk bulundukları bölgelerden göçe zorladı. Bu baskıya dayanamayan sivil halk kitleler halinde (yaklaşık 2-3 milyon) Kuzey Irak'taki dağlık bölgelere kaçtı. 250.000 Kürt kökenli sivil halk Türkiye sınırına dayandı. İran-Irak sınırında tam 500.000 sığınmacı tespit edildi. ${ }^{17} \mathrm{Bu}$ göç sırasında günlük yaklaşık bin kişi dağlarda açlıktan ve soğuktan hayatını kaybetti.

2 Nisan 1991'de Türk Hükümeti Güvenlik Konseyi'nin dikkatini çekti Kuzey Irak'taki bu duruma çekti. ${ }^{18}$ Aynı şekilde İran Hükümeti de 3 ve 4 Nisan 1991tarihinde verdiği iki nota ile aynı konuda uluslararası toplumu uyard. ${ }^{19}$ Türkiye ve İran'ın başvurusu üzerine 5 Mayıs 1991 tarihinde Güvenlik Konseyi harekete geçti. Fransa ve Belçika'nın da dahil olmasıyla 4 Nisan 1991 tarihinde Güvenlik Konseyi'ne bir karar tasarısı sunuldu. ${ }^{20}$ Bunun üzerine de Güvenlik Konseyi S/ RES/688 (1991) sayılı kararı aldı. Bu kararda Iraklı sivil halka yapılan baskılar kınanmış ve bu baskıların sona erdirilmesi ve diyalog yolunun açılması istenmiştir. Aynı zamanda Irak Hükümeti'nden, yardıma muhtaç durumda olan bu sivil halka yardım etmek için çalışan yardım organizasyonlarına engel olmaması talep edilmiştir. ${ }^{21}$ Konsey ayrıca kitlesel göçleri doğuran özellikle kuzeydeki Kürt sivil halka yapılan baskıları kınamış ve bu konudaki endişelerini bu kararında dile getirilmiştir. ${ }^{22}$

17 Herbst, Jochen, Rechtskontrolle des UN-Sicherheitsrates, Frankfurt, Berlin, 1999, s. 217.

18 Türk Hükümeti'nin Güvenlik Konseyi'nden talebi: „to adopt the necessary measures to put an end to the inhuman repression being carried out on a massive scale against the local population in Northern Iraq, pressing these people towards the Turkish border and constituting a threat to the region's peace and security." UN-Doc. S/22435 (02.04. 1991). Ayrıca bu konuda bkz. UN-Doc. S/PV. 2982 (05.04. 1991), s. 3 vd. (Güvenlik Konseyi’ndeki Türk temsilcinin açıklamas1).

19 UN-Doc. S/22436 ( 03. 04. 1991); UN-Doc. S/22447 (04. 04. 1991).

20 Güvenlik Konseyi Başkanı'na sunulan Fransa'nın 04.04.1991 tarihli mektubu (UN-Doc. S/22442, s. 1).

21 S/RES/688 (1991) 1. Condemns the repression of the Iraqi civilian population in many parts of Iraq, including most recently in Kurdish-populated areas, the consequences of which threaten international peace and security in the region; ( ... )

2. Demands that Iraq ( ... ) immediately end this repression ( ... )

3. Insists that Iraq allow immediate access by international humanitarian organizations to all those in need of assistance (.. )".

22 UN-Doc. S/RES/688 (1991) -1.op.para: „Condemns the repression of the Iraqi civilian population in many parts of Iraq, including most recently in Kurdish-populated areas,...”. 
$\mathrm{Bu}$ karardan üç gün sonra $\mathrm{AB}$ zirvesinde İngiltere tarafindan Kuzey Irak’ta BM çerçevesinde güvenli bölge oluşturulması teklifi yapıldı. ${ }^{23}$ İki gün sonra da ABD tek taraflı olarak, 36. paralelin kuzeyini uçuşa yasak bölge (no fly zone) ilan ederek, Irak Hükümetini, herhangi bir askeri operasyon yapmaması, özellikle de havadan saldırı düzenlememesi konusunda uyardı. ${ }^{24} \mathrm{Bu}$ kararın alınmasındaki ana amaç, Irak’taki ve Türkiye'deki Kürtlerin evlerine geri dönmelerinin sağlanmas1, yeni mülteci akımlarının engellenmesi, Kürt mültecilerin Irak ordusunun saldırılarından güvende olması, mültecilere yardım malzemelerinin dağıtılmasının sağlanmasıyd $1 .{ }^{25} \mathrm{Bu}$ kararı Irak Hükümeti protesto etti. ${ }^{26}$ Amerikan Hükümeti de oluşturulan bu güvenli bölgenin geçici olduğunu, güvenli bölgenin idaresinin ve güvenliğinin sağlanmasının en kısa zamanda BM'ye devredileceğini açıkladı. ${ }^{27}$

17.04.1991 tarihinde ABD önderliğindeki İngiltere, Fransa ve Türkiye'den oluşan koalisyon güçleri, bölgeye güvenli bölge oluşturarak müdahale etti ve mülteci kampları kurdu. ${ }^{28}$

Koalisyon birliklerinin bu karar ve uygulamalarının hukuksal temelinin Güvenlik Konseyi'nin S/RES/688 sayılı kararı olduğu ileri sürülmektedir. Ancak bu kararda koalisyon güçleri ne BM Sözleşmesi'nin VII. bölümü çerçevesinde açık bir şekilde yetkilendirilmiş ve ne de örtülü bir şekilde güvenli bölge kurma görevi ile görevlendirilmiştir. ${ }^{29}$

Sonuç olarak 1991 yılında ABD önderliğindeki koalisyon güçleri tarafından Kuzey Irak'ta oluşturulan güvenli bölge her ne kadar daha sonra BM tarafindan organize edilmişse de BM'nin klasik önlemlerinden değildir ve BM tarafindan açık bir yetkilendirme olmadan uygulamaya konulmuştur. ${ }^{30}$

\subsubsection{Güvenli Bölgenin (Safe Havens) Güvenliği ve İdaresi}

Güvenli bölge operasyonundan iki gün sonra 18.04.1991 tarihinde Irak Hükümeti ile BM bir anlaşma imzaladı. Bu anlaşmayla Irak Hükümeti BM’ye insa-

23 Archiv der Gegenwart 1991, 35564.

24 Malannczuk, The Kurdish Crisis and Allied Intervention in the Aftermath of the Second Gulf War." European Journal of International Law, 2 (1991), s. 120 d. ; Endemann, Harald, Kollektive Zwangsmaßnahmen zur Durchsetzung humanitärer Normen, in: AJIL 93 (1999), s. 189.

25 Endemann, s. 187; Hottinger, Die arabische Welt nach dem Golfkrieg, , EA 46 ( 1991 ), s. 442.

26 Freedman, Lanwrence,/Boren, David, "Safe Havens" for Kurds in Post-War Iraq in: To Louose, the Bands of Wickedness: International Intervention in Defence of Human Rights, ed.Nigel S. Rodley London 1992, s. 56.

27 Archiv der Gegenwart 1991, 35567; Endemann, s.187 d.

28 FreedmannlBoren, s. 56.

29 Fink, Udo, Kollektive Friedenssicherung II, Kapitel VII UN-Charta in der Praxis des Sicherheitsrats der Vereinten Nationen, Frankfurt, 1999, s. 604; Endemann, s.189 vd; Malanczuk, s. 122 vd.; Landgren, s. 443.

30 Simon, s. 14. 
ni yardımlar konusunda işbirliği yapmayı taahhüt etti. ${ }^{31}$ Hükümet öncelikle sivil yardımcilara ve sivil insani yardım merkezlerine izin verdi. Sonradan koalisyon birlikleri ve Irak Hükümeti, güvenli bölgenin idaresinin BM'ye bağlı bir polis birliği tarafından üstlenilmesi konusunda BM'yi razı etti. Böylece 23.05.1991 tarihinde koalisyon güçleri tarafindan gönderilen 500 kişilik bir birlik, polis birliğinin yerini aldı. Bu birlik, yapılan anlaşma çerçevesinde yardımların ve göçmenlerin evlerine dönüşlerinin organize edilmesi için yetkilendirildi. ${ }^{32}$ Bunun yanında ayrıca Kürtleri korumak için Türkiye'de 5000 kişilik hızlı müdahale birliği kuruldu. ${ }^{33} \mathrm{Bu}$ birliğin görevleri arasında "Operation Provide Comfort I" çerçevesinde uçuşa yasak bölgede bu yasağa riayet edilmesini sağlamak da vard1.

$\mathrm{Bu}$ arada Kürt liderler Irak Hükümeti ile otonomi için görüşmeler yürütmeye başladı. 24.07.1991 tarihinde insani yardımların organizesi görevini "Operation Provide Comfort II" misyonu üstlendi. Bu birliklerin ana görevi güvenli bölgelerin saldırılardan korunmasıyd $1{ }^{34} \mathrm{Bu}$ birliğin görevi de 1996 yılının sonunda bitti. 1997 y1l başı itibarıyla ABD, İngiltere ve Türkiye tarafından oluşturulan yeni bir askeri misyon (Operation Northern Watch) bölgeyi koruma altına aldı. Bu misyonun görev tanımı içinde ağırlıklı olarak uçuşa yasak bölgenin gözlemlenmesi ve kitle imha silahlarına ilişkin çalışmalar vardı. Artık insani yardımlara ilişkin bir görev tanımı bulunmamaktayd1. ${ }^{35}$

\subsubsection{Güvenli Bölgede İnsani Standart ve Koruma}

Koalisyon birliklerinin hava saldırılarının caydırıcı rolü ve daha sonraki acil müdahale birliğinin etkisi güvenli bölgede Kürt halkına önemli ölçüde koruma sağladi. Genel olarak koalisyon güçlerinin tehdit potansiyeliyle oluşan güvenli ortam, 450.000 kişinin evlerine geri dönmelerini sağladı. Ayrıca bu bölgedeki sivil halka herhangi bir engelleme olmaksızın insani yardım sunulabildi. Ancak bütün bu önlemlere rağmen 13.000 kişi güvenli bölgeye ulaşamadan hayatını kaybetti. ${ }^{36}$

Güvenli bölgedeki koalisyon güçlerinin otorite ve tehdit potansiyelinin ortadan kalkması ve bölgenin silahlardan arındırılmasındaki eksiklik, bölgede özerklik hareketlerini güçlendi. Bu gelişmelerden rahatsız olan Irak Hükümeti de güvenli bölgeye gelen insani yardımları bloke ederek ve güvenli bölgeye saldırı düzenleyerek tepki verdi. Yani oluşturulan güvenli bölge Kürt bölgesel yönetimiyle Irak Hükümeti arasındaki problemin çözümünü sağlayamadı. ${ }^{37}$

31 S/22663 18 Nisan 1991; Freedman/Boren, Safe Havens, s. 59 vd.

32 Simon, s.18.

33 Endemann, s. 189.

34 Simon, s. 18.

35 Simon, s.20.

36 Simon, s. 19.

37 Simon, s. 21. 
Bir taraftan BM tarafindan Irak'a uygulanan ekonomik ambargo, diğere taraftan Irak Hükümeti'nin bölgeye uyguladığı ambargo Kuzey Irak'ta oluşturulan güvenli bölgede insani durumu olumsuz etkiledi. ${ }^{38}$ Bütün bu olumsuzluklara rağmen 1994 yılında bu bölgede gerekli gıda ihtiyacı \% 70 oranında sağlanmıştır. Aynı zaman dilimi içinde Orta ve Güney Irak’ta gıda maddesi ihtiyacı karşılama oran1 $\% 40{ }^{\prime}$ trr. $^{39}$

\subsection{Safe Area Bosna-Hersek 1993}

1991 yılında Yugoslavya'nın dağılması ve ardından Bosna-Hersek'in bağımsızlık ilan etmesiyle birlikte iç savaş yayıldı. Savaş bölgelerinde BMMYK ve Uluslararası Kızıl Haç Komitesi geniş çapta insani yardım organize etmekteydiler. Bu yardım faaliyetleri özellikle Bosnalı Sırplar tarafından sıkça engellenmekteydi. Güvenlik Konseyi S/RES/758 sayılı kararla Hırvatistan topraklarında gözlemci misyon olarak bulanan Birleşmiş Milletler'in barış gücü United Nations Protection Forces (UNPROFOR)'un görev kapsamına Bosna'y1 da kattı. Konsey, S/RES/776 (1992) $)^{40}$ sayılı kararla yardımların ulaştırılmasını UNPROFOR'un görev alanına dahil etti.

Bosnalı Sırp savaşçıların etnik temizlik politikaları 1993 yılında Bosna'daki durumu acil insani yardım durumuna dönüştürdü. Sırp olmayan unsurlara karş1 ağır insan hakları ihlalleri, insani yardım konvoylarının engellenmesi, UNPROFOR'un çalışmalarının engellenmesi, yine aynı şekilde Sırp savaşçılar tarafından kendi bölgelerinde kalan Müslümanların tehdit edilmesi, bölgedeki insani yardım organizasyonlarının uluslararası topluma acil yardım çağrısında bulunmasına yol açt1. ${ }^{41}$

16.04.1993 tarihinde Konsey S/RES/819 say1lı kararyyla Srebrenica'y1 güvenli bölge ilan etti ve 06.05.1993 tarihinde S/RES/824 ${ }^{42}$ sayıl1 kararla da Sarayevo, Tuzla, Gorazde ve Bihaç'1 da güvenli bölgeye dahil etti. Konsey bu kararları alırken BM Sözleşmesi'nin VII. Bölüm hükümlerine dayandı. Silahlı çatışmaların taraflarının bu kararı kabul eden bir açıklaması olmadı. Esas olarak VII. Bölüm kapsamındaki BM Güvenlik Konseyi kararının bağlayıcılığı karşısında silahlı çatışmaların taraflarının bu kararı kabul edip etmemesinin uluslararası alanda bir önemi bulunmamaktadır.

38 UNHCR, The State of the World's Refugees, 2000, 217.

39 Simon, s. 21.

40 S/RES/776, 13.14.9.1992, para. 2.

41 Simon, s.22.

42 S/RES/824 (1993): "That the capital city of the Republic of Bosnia and Herzegovina, Sarajevo and the other threatened areas, in particular the towns of Tuzla, Zepa, Gorazde, Bihac as well as Srebrenica and their surroundings hould be treated as safe areas by all the parties concerned and should be free from any armed attacks and from any other hostile act." 
Güvenli bölge, Bosnalı Sırp savaş̧̧ıların saldırılarından sivillerin korunması, yardım malzemelerinin dağıtılmasının garanti altına alınması ve böylelikle başka göç dalgalarının olmasına engel olunması gibi daha çok insani hedefler için ihdas edilmişti. ${ }^{43} \mathrm{Bu}$ önlemlerin bir diğer sonucu da barış görüşmelerine olumlu etki sağlamaktı. ${ }^{44}$

\subsubsection{Güvenli Bölgenin Güvenliği ve İdaresi}

02.01.1992 yılında Cyrus Vance-Barış planı imzalandı. Bu plana göre Birleşmiş Milletler'in barış gücü UNPROFOR da bölgeye yerleşecekti. Güvenlik Konseyi 21.02.1992 tarihinde aldığı S/RES/743 (1992) sayılı kararıyla UNPROFOR'un kurulmasina karar verdi. ${ }^{45}$

Bütün bu gelişmelere rağmen, Bosna-Hersek’teki sivil halka insani yardımın ulaştırılması, çatışan tarafların yardım konvoylarının hedeflerine ulaşmalarına engel olmaları ya da zorlaştırmaları suretiyle engellenmekteydi. Yolda yardım konvoyları sürekli ya soyuluyor ya da silahlı saldırıya uğruyordu. Yardım konvoyları için güvenlik koridorlarının oluşturulması ve bu koridorların barış gücü tarafından kontrol edilmesini kurala bağlayan anlaşma uygulanamadı. Bunun üzerine Güvenlik Konseyi 13.06.1992 tarihinde S/RES/764 (1992) sayılı kararı alarak Saraybosna ve çevresini güvenli bölge ilan etti. Aynı kararda Konsey, taraflardan Saraybosna ve çevresinin haricindeki bölgelere insani yardım ulaştırılması amacıyla UNPROFOR ile işbirliği yapmalarını istedi. Bütün bu kararlara rağmen Bosna-Hersek'deki hapishanelerde ve tutuklama kamplarında kötü muameleler yapıldığ 1 , tutuklanan sivillere işkence edildiğine dair haberler medyada yer aldı. Bunun üzerine Konsey 13.08.1992 tarihinde S/RES/770 (1992) sayılı kararı aldı. $\mathrm{Bu}$ kararda Konsey gelen haberlere ilişkin derin endişelerini dile getirmiş ve taraflardan Uluslararası Kızıl Haç Komitesi ve diğer insani yardım organizasyonlarına bu yerlere giriş imkânı ve izni vermesini ve tutuklulara insanca davranılmasını, yani bu kişilerin gıda, barınak ve ilaç ihtiyaçlarının giderilmesini istemiştir. ${ }^{46}$

Konsey yine bundan sonra aldığı S/RES/771 (1992) sayılı kararla, savaş sırasinda Eski Yugoslavya'da ve özellikle Bosna-Hersek’te sivillerin kitlesel olarak yerlerinden çıkartılması ve toplama kamplarına yerleştirilmesi ve bu kamplarda işkence görmeleri, savaşçı olmayanlara, hastanelere, ambulanslara yapılan sald1rılar, ihtiyaç sahiplerine tıbbi malzemelerin ve gıdaların ulaştııılmasının engel-

43 Report of the Special Rapporteur of the UN Human Rights Commission, E/CN.4/1992/S-1I10, 27.10.1992, para. 25 (b); ICRC Press Release No. 1728, 3.10 .1992 "Saving Lives in Bosnia-Herzegovina".

44 UN-Doc S/RES/824 (1993), “( ... ) Convinced that treating the towns referred to above as safe areas will contribute to the early implementation of the peace plan ( ... )".

45 Demirel, s. 182

46 Demirel, s. 186. 
lenmesi, kasti olarak mallarının tahrip edilmesi konularına ilişkin üzüntülerini ifade etmiştir. ${ }^{47}$

BM Güvenlik Konseyi 14.09.1992 tarihinde aldığ1 S/RES/776 sayılı kararıyla insani yardım malzemelerinin yerlerine ulaştırılmasının sağlanması için 7000 kişilik bir barış gücü (UNPROFOR) oluşturdu. 08.05.1993 tarihinde de Bosna hükümetiyle Bosnalı Sırplar, Srebrenica ve Zepa'nın silahtan arındırılmış bölge olması konusunda anlaşma imzaladılar. ${ }^{48}$

BM tarafından oluşturulan koruma alanlarında sivillerin zorla yerlerinden çıkartılması suretiyle "etnik temizlik" hareketlerinin yapıldığına ve malvarlıklarının yağmalandığına dair çıkan haberler üzerine Güvenlik Konseyi harekete geçti. ${ }^{49}$ Kasım 1992'de BM Genel Sekreteri, BMMYK ve diğer uluslararası insani yardım örgütleriyle birlikte Eski Yugoslavya' da insani amaçlı "güvenli bölge" oluşturma imkânlarını araştırmakla görevlendirildi. ${ }^{50}$ Güvenlik Konseyi gıda maddelerinin ve tıbbi malzemelerin sivil halka ulaştırılmasına engel olan kişilerin takip edileceğini de bildirmiştir. ${ }^{51}$

Daha sonra, taraflar arasında kalıcı bir barış anlaşması sağlamak amacıyla yürütülen Vance-Owen Planı çerçevesindeki görüşmelerinden olumlu bir sonuç alınamaması, taraflar arasındaki anlaşmaya riayet edilmemesi, güvenli bölgeye Sirp saldırılarının devam etmesi, Bosnalı Sırplar tarafindan yardım konvoylarının engellenmesi, UNPROFOR'un serbest dolaşımının engellenmesi fillerinin devam etmekte olması sebebiyle BM çevrelerinde güvenli bölge rejiminin güçlendirilmesine ilişkin arayışlar başlad1. ${ }^{52}$ Güvenlik Konseyi Nisan 1993 'te aldığ 1 bir kararla Srebrenica bölgesindeki durum üzerine bir değerlendirme yapmıştır. Bu kararda Konsey suçsuz sivillerin Bosnalı Sırp paramiliter grupların saldırısına uğramaların $1^{53}$ ve birçok sivilin özellikle kadınların, çocukların ve yaşlıların göçe

47 UN-Doc. S/RES/771 (1992) -6.op.para: ..Requests the Secretary-General to collate the information....and to submit a report to the Council summarizing the information and recommending additional measures that might be appropriate in response to the information;".

48 The Fall of Srebrenica, para. $59 \mathrm{vd}$, para. $63 \mathrm{vd}$.

49 UN-Doc. S/RES/779 (1992) -4.pr.para:.Expressing grave alarmat continuing reports of ,ethnic clean-sing" in the UNPAs and of forcible expulsion of civilians and deprivation of their rights of residence and property,...".

50 UN-Doc. S/RES/787 (1992) -19.op.para: "Invites the Secretary-General...to study the possibility of and the requirements for the promotion of safe areas for humanitarian purposes.."

51 UN-Doc. S/RES/787 (1992) -7.op.para: "Condemns...the deliberate impeding of the delivery of food and medical supplies to the civilian population of the Republic of Bosnia and Herzegovina, and reaffirms that those that commit or order the commission of such acts will be held individually responsible in respect of such acts," aynı şekilde UN-Doc. S/RES/824 (1993).

52 The Fall of Srebrenica, para. 70 d.; Fink, Friedenssicherung II, s. 654 vd; Giersch, Carsten, Konfliktregulierung in Jugoslawien, Konfliktregulierung in Jugoslawien 1991-1995: Die Rolle von OSZE, EU, UNO und NATO, Baden-Baden 1998, s. 244 d.

53 UN-Doc. S/RES/819 (1993) -7.pr.para. 
zorlanmasını kabul edilmez bulmuş ve bu olaylar neticesinde bölgede acil insani yardım durumu olduğunu tespit etmiştir. ${ }^{54}$

06.05.1993 tarihinde toplanan Güvenlik Konseyi, içinde hasta ve yaralıların da bulunduğu yerlerinden çıkartılanların Bosna-Hersek'in bazı şehirlerine göçmeleriyle birlikte insani acil yardım durumu halinin daha da kötüleşmiş olduğunu tespit etmiştir. ${ }^{55}$ Konsey, Saraybosna, Tuzla, Zepa, Gorazde, Bihac ve Srebrenica'yı güvenli bölge ilan etmiş ve bu bağlamda paramiliter Bosnalı Sırp birliklerinin yaptıkları saldırıları durdurmalarını istemiştir. ${ }^{56}$

08.05.1993 tarihinde de Bosna hükümetiyle Bosnalı Sırplar, Srebrenica ve Zepa'nın silahtan arındırılmış bölge olması konusunda anlaşma imzaladılar. ${ }^{57}$

BM Güvenlik Konseyi 04.06.1993 tarihinde S/RES/836 sayılı kararıla sadece insani yardım alanında görevli olan UNPROFOR'un görev alanını genişletti. Bu kararla birlikte artık güvenli bölgeye yapılacak saldırılara engel olmak, ateşkesi denetlemek, Bosnalı Sırpların askerlerinin ve paramiliter silahlı gruplarının çekilmelerini sağlamak ve güvenli bölgedeki önemli kilit noktaların kontrol edilmesi UNPROFOR'un yetkisine dahil edilmiş olmaktayd $1 .{ }^{58}$ Kararda aynı zamanda güvenli bölgeye gelen yardım konvoylarının engellenmesi, UNPROFOR'a ve güvenli bölgeye saldırılması halinde UNPROFOR'a silahla karşıllık verme hakkı getirilmişti. Yine bu kararla üye devletlere UNPROFOR'un görevini ifa ederken gerekli her türlü desteğin hava saldırılarıyla sağlanması yetkisi verilmişti.

Güvenli bölgenin güvenliğinin sağlanması konusunda uygulamada başlangıçta, yaşanan tereddütten sonra, ${ }^{59}$ Güvenlik Konseyi’nin S/RES/836 sayılı ka-

54 UN-Doc. S/RES/819 (1993) -7.pr.para:.”. UN-Doc. S/RES/819 (1993): “..Aware that a tragic humanitarian emergency has already developed in Srebrenica and its surrounding areas as a direct consequence of the brutal actions of Bosnian Serb paramilitary units, forcing the large-scale displacement of civilians, in particular women, children and the elderly,".

55 UN-Doc. S/RES/824 (1993) -5.pr.para.

56 UN-Doc. S/RES/824 (1993) -7.pr.para: "Deeply concerned at the continuing armed hostilities by Bosnian Serb paramilitary units against several towns in the Republic of Bosnia and Herzegovina and deter-mined to ensure peace and stability throughout the country, most immediately in the towns of Sarajevo, Tuzla, Zepa, Gorazde, Bihac, as well as Srebrenica".

57 S/125700, (30.4.1993). Bu sözleşmede Bosna hükümet birliklerinin silahlarını UNPROFOR'a teslim etmesini, bunun karşılığında Sırpların ağır silahlarını geri çekeceklerdi.

58 UN-Doc S/RES/836 (1993) para 5: "Decides to extend to that end the mandate of UNPROFOR in order to enable it, in the safe areas ( ... ), to deter attacks against the safe areas, to monitor the cease-fire, to promote the withdrawal of military or paramilitary units other than those of the Government of the Republic of Bosnia and Herzegovina and to occupy some key points on the ground, in addition to participating in the delivery of humanitarian relief to the population as provided for in resolution 776 (1992) ( ...)".

59 Simon, Annette/Vandenberghe, Brecht, Der Fall der UN "Safe Area" Srebrenica und die Rolle des niederlaendischen Bataillons Dutchbalt eine Zusammenfassung der niederlaendischen Untersuchengen, in: ZaöRV 2001, s. 687 d.; Weller, M (ed) Peace)-Keeping and Peace-Enforcement in the Republic of Bosnia and Herzegovina in: in: ZaöRV 2001, s.113 vd. 
rarında yer alan üye devletlerin havadan desteği ifadesi UNPROFOR'un hem savunulması ve hem de görevi çerçevesindeki faaliyetlerinin desteklenmesi şeklinde yorumladı ${ }^{60}$ Daha sonra BM Güvenlik Konseyi'nin hava saldırı hedefi kapsamına Hırvatistan'daki Sırpların ağır silahlarının bulunduğu yerleri de dâhil edildi. $^{61}$

\subsubsection{Exclusion Zones ve Ateşkes Andlaşması}

28.02.1994 tarihinde NATO uçakları uçuş yasağını ihlal eden 4 Sırp askeri uçağını düşürdü. Bundan sonra çatışmaların ağırlıklı noktası geçici de olsa Saraybosna'dan BM'nin güvenli bölge ilan ettiği Tuzla, Zepa, Gorazde, Bihac ve Srebrenica'ya kayd $1 .{ }^{62}$

1994 baharında Sirplar güvenli bölgeye, Saraybosna'ya ve Gorazde'ye saldırmaya devam ettiler ve sayısı 7600'a çıkartılan UNPROFOR birliklerinden bazı askerleri de rehin aldılar. Bunun üzerine NATO, BM Genel Sekreteri'nin de isteğine uyarak, çatışan taraflara, ağır silahlarını sınırları belirlenen Saraybosna ve Gorazde'den çekmeleri yönünde ültimatom verdi, ${ }^{63}$ aksi şekilde davranış NATO hava saldırılarına hedef olmak olacaktı. ${ }^{64} \mathrm{Bu}$ ültimatom sayesinde güvenli bölge Gorazde'ye ilişkin ateşkes ve silahsızlandırma anlaşmaları yapılabildi. Yine aynı şekilde UNPROFOR'un Saraybosna'daki serbest dolaşımını öngören ${ }^{65}$ çeşitli anlaşmaların yapılması mümkün oldu. ${ }^{66}$

1994'ün sonbaharında güvenli bölge Bihac'a Sırplar saldırdı. Bu olay karş1sında BM Güvenlik Konseyi tarafları uzlaşmaya ve işbirliğine çağırdı. Bu çağrıların hiçbir etkisi olmaması üzerine Haziran 1995 'te Fransa ve İngiltere'nin inisiyatifiyle UNPROFOR askerlerinin korunması ve görevini yapabilmesi için acil müdahale birliği (RRF) oluşturuldu ${ }^{67}$ ve bu birlik BM Güvenlik Konseyinin S/ RES/998 sayılı kararıyla göreve başladı. ${ }^{68}$

60 UNSG-Report, S/1994/555, (9.5.1994), para. 13.

61 UN-Doc S/RES/958 (1994).

62 Gading, Heike, Der Schutz grundlegender Menschenrechte durch militarische Massnahmen des Sicherheitsrates - das Ende staatlicher Souveranitat?, Berlin 1996, s. 113.

63 The Meeting of the North Atlantic Council on 22. 04. 1994, EA, 21/1994, D 627-629.

64 NATO Konseyi Kararı (09.02.1994), Mektup Nr.1/1994.

65 The Fall of Srebrenica, para. $120 \mathrm{vd}$.

66 Simon, s. 27.

67 Simon, s. 27; The Fall of Srebrenica, para. 213 H.; Weller, s.150 .

68 UN-Doc S/RES/998 (1995). para.9: "welcomes the letter of the Secretary General of 9 June 1995 on the reinforcement of UNPROFOR and the establishment of a rapid reaction capacity to enable UNPFIUNPROFOR to carry out its mandate; 10. Decides accordingly to authorize an increase in $U N P F / U N P R O F O R$ personnel, acting under the present mandate and on the terms set out in the above-mentioned letter, by up to 12.500 additional troops, the modalities of financing to be determined later ( ... )", 


\subsubsection{Srebrenica ve Zepa Güvenli Bölge Olayı}

13 Nisan 1993 tarihinde Bosnalı Sırplar, Srebrenica'nın iki gün içinde boşaltılması ültimatomunu verdi. Bu tehdit üzerine Güvenlik Konseyi 16.04.1993 tarihinde S/RES/819 sayılı kararı aldı. Bu kararda Srebrenica güvenli bölge olarak ilan edildi. Kararda Konsey, Srebrenica ve çevresinde suçsuz sivillerin Bosnalı Sırp paramiliter grupların saldırısına uğramasının ve birçok sivilin özellikle kadınların, çocukların ve yaşlıların göçe zorlanmasının kabul edilmez olduğunu ifade etti. 18.04.1993 tarihinde 170 UNPROFOR askeri Srebrenica'ya girdi. 06.05.1993 tarihinde Güvenlik Konseyi S/RES/824 say1lı kararıla Srebrenica'nın güvenli bölge statüsü hatırlattı. 04.06.1993 tarihinde S/RES/836 sayılı kararlarla Konsey yine bu statüyü hatırlatarak, UNPROFOR askerlerine kendilerini savunmak amaciyla silah kullanma yetkisi verdi. Bundan sonra Mart 1994 tarihinde Srebrenica' da Hollandalı askerler güvenli bölgeyi oluşturdular. Ancak Bosnalı Sırplar askerden arındırma kararına uymayarak şehri bulundukları yerlerden tehdit etmeye devam ettiler, yardım konvoylarına engel oldular. Bu durum da şehirdeki sivillerin durumlarını sürekli kötüleştirdi.

Ocak 1995'ten sonra Sırp saldırıları yoğunlaştı. Sırplar, insani yardım konvoylarını engelleyerek 100 kişiyi daha rehin aldılar ve bazı UNPROFOR askerleri hayatlarını kaybetti. Bu olaylar sırasında 1000-2000 kişilik Bosnalı Sırp savaşçılara karşılık olarak 600 hafif silahlı Hollanda askeri bulunmaktaydı bölgede. Srebrenica'da kalan hükümet birlikleri 3000-4000 kişilik bir sayıya sahipti. Bu birlikler her ne kadar sayıca çok olsalar da silahlardan arındırma ve silah amborgosu sebebiyle yeterli silaha ve eğitime sahip değildiler. ${ }^{69}$

11.07.1995 tarihinde Hollandalı UNPROFOR askerleri Bosnalı Sırplara karş1 tek bir kurşun bile sıkmadan Srebrenica'nın merkezini Bosnalı Sırp birliklere teslim etti. Sivil halk UNPROFOR'un kampının bulunduğu Potocari kentine kaçt1. BM Güvenlik Konseyi 12.07.1995 tarihinde aldığı S/RES/1004 sayılı kararla Sırplardan Srebrenica'ya karşı saldırılarını durdurması, güvenli bölgeyi boşaltması ve bölgeye gelen insani yardımların yolunu açmasını istedi. Bosnalı Sırpların bu çağrıya cevabı Müslüman sivil halkı ağır insan haklar ihlalleri ve kötü muamele eşliğinde kitlesel olarak göçe zorlamaya devam şeklinde oldu. ${ }^{70}$

25.07.1995 tarihinde sadece 120 UNPROFOR askeri tarafindan korunan Zepa güvenli bölgesi Bosnalı Sırp askerlerin saldırısı sonucunda Sırp kontrolüne geçti. $^{71}$ 30.08.1995 tarihinde NATO Operation Deliberate Force adlı hava saldırılarına başlayarak diğer güvenli bölgelerin Sırpların eline geçmesine engel oldu. $\mathrm{Bu}$ hava saldırıları Sırpları Bihac, Gorazde, Saraybosna ve Tuzla güvenli bölgelerine

69 The Fall of Srebrenica, para. 230, $476 \mathrm{H}$.

70 The Fall of Srebrenica, para. $318 \mathrm{H}$.

71 The Fall of Srebrenica, para. $421 \mathrm{vd}$. 
dönük tehdit ve saldırılardan alıkoydu ve aynı zamanda ülkenin diğer bölgelerinde de düşmanca eylemlerden vazgeçme taahhüdünde bulunmaya itti. 14.12.1995 tarihinde Hirvatistan, Yugoslavya, Bosna Hükümeti ve Bosnalı Sirplar arasında Paris'te bir barış anlaşması yapıldd. ${ }^{72}$ Bunun üzerine BM Güvenlik Konseyi'nin 15.12.1995 tarihinde aldığı S/RES/1031 sayılı kararla güneli bölgenin güvenliğinin sağlanması görevi de UNPROFOR'dan NATO tarafından idare edilen IFOR'a geçti. Güvenli bölge uygulaması görevi de barış anlaşmasıyla sona erdi.

\subsubsection{Güvenli Bölgenin Korunması ve İnsani Standart}

1995 yılında Bosnalı Sırpların zulmü Srebrenica ve Zepa'da dayanılmaz dereceye ulaşmıştı. Sırpların kontrolü altındaki bölgelerde yaşayan Müslümanlara yardımların ulaştırılması Sırp birliklerin engellemeleri sebebiyle tam bir güven içinde sağlanamıyordu. ${ }^{73} 1994$ kışında gerekli olan insani yardımın ancak yarısı güvenli bölgelere ulaştırılabildi. ${ }^{74}$ Gorazde' de insani yardım ihtiyacının sadece sadece \% 40’ı karşılanabildi ve hastanelerde ilaçsızlıktan bir çok insan hayatını kaybetti. $^{75}$

Sırpların UNPROFOR gücünü ve insani yardım personelini engellemesi ve hatta onlara saldırmasına rağmen ${ }^{76}$ uluslararası toplum tarafından alınan önlemlerin ${ }^{77}$ özellikle NATO birliklerinin (Operation Deliberate Force) Sirp birliklerini düzenli olarak ateş altına almasının ve havadan bombalamasının güvenli bölgelerdeki genel insani durum ve güvenliğin iyileşmesine önemli katkısı olduğu söylenebilir. ${ }^{78}$

Bosna'daki bir diğer sorun da güvenli bölgelere sivil Müslüman nüfusun gelmesinin engellenmesiydi. Bunun sebebi bir taraftan Bosna Hükümeti'nin bu tür nüfus hareketlerine yasak getirmesi, diğer taraftan da bu kişilerin Sırp kontrol bölgelerine girmesine Sırpların engel olmasıyd.$^{79} \mathrm{Bu}$ bölgelerde hala çatışmaların sürüyor olması da bir başka engeldi.

72 General Framework Agreement for Peace in Bosnia and Herzegovina, Paris 14.12.1995, ILM Vol. 35 (1996), 89 vd. in: http://www.osce.org/bih/126173?download=true

73 UNHCR, The State of the World's Refugees, 2000, s. 227, in: http://www.unhcr.org/publications/sowr/4a4c754a9/state-worlds-refugees-2000-fifty-years-humanitarian-action.html.

74 UNSG-Report, S/1994/1389, 01.12.1994, para. 5.

75 E/CN.4/1994/110, para. 67.

76 UNHCR, The State of the World's Refugees,2000, $226 \mathrm{~d}$.

77 Ogata, Sadako, UNHCR in the Balkans, humanitarian Action in the Midst of War, in: Biermann, W.Nadset, M., UN Peacekeeping in Trouble: Lessons Learned from the Former Yugoslavia, 1998, s. 189.

78 Tiso, Christoper.M., Safe Haven Refugee Programs: A Method of Combating International Refugee Crises, Georgetown Immigration Law Journal, 8 (1994), s. 584; Lupis, Ivan, Human rights abuses in the wake of the collapse of the United Nations-designated 'safe area' of Srebrenica and the international community, Helsinki Monitor, 1 (1996) s. 66 vd.

79 UNHCR, The State of World's Refugees, 1995, s.129. 
Güvenli bölgeler, birçok insanın hayatını kurtarmasının yanında gerçekte sunması gereken koruma ve insani yardımı sunamad1. Gerek güvenli bölgelerin silahlardan arındırılması ve gerekse UNPROFOR'un yetkilerindeki eksiklikler ve buna bağlı olarak Sırpların saldırıları ve engellemeleri sebebiyle bu bölgede yaşayan insanların hayatları tehlikeye atılmış oldu. Hayatını koruma ve sürdürme düşüncesiyle sözde güvenli bölgelere göç eden siviller için bu bölgeler birer tuzak fonksiyonu gördü. BM barış gücü güvenli bölgelerin güvenliğinin sağlanması hususunda zayıflık gösterdi ve silah kullanmadan Srebrenica ve Zepa'y1 Sirplara teslim etti.

Bir diğer kötülük ise bu bölgede yaşayan insanların bu bölgeden kaçmalarına BM gücü tarafından izin verilmemesiydi. Bu uygulama bu bölgeleri böylelikle açık bir hapishaneye dönüştürdü. Sırp birliklerine karşı BM güçlerinin Srebrenica'yı gereği gibi korumaması sebebiyle binlerce insan katledildi. Daha sonra Yugoslavya Savaş Suçları Mahkemesi'ndeki savaş suçlarına ilişkin davalar ve başka araştırmalar vesilesiyle ortaya çıkartılan ve görüntülerle haberleştirilen Sırp savaşçılarının yaptığı insan hakları ihlalleri, sürgün ve kitlesel kıyımlar, toplu mezarlar, BM'nin Srebrenica'daki güvenli bölge uygulamasının başarısızlığını ortaya koyan deliller olarak değerlendirilmiştir. Bu sebeple burada özellikle 1995 yılında Bosna'nın Srebrenica şehrinde oluşturulan güvenli bölgedeki BM'nin Barışı Koruma Gücü'nün dramatik başarısızlığını ifade etmek gerekir.

BM Genel Sekreteri'nin konuya ilişkin sunduğu araştırma raporuna göre ortaya çıkan bu dramatik sonucun sebebinin güvenli bölge uygulamasının kendisinde değil, uluslararası toplumun kararlı bir şekildeki bu tedbiri uygulayamamasında aranması gereklidir. ${ }^{80}$

\subsection{Güvenli İnsani Bölge-Güney-Doğu Ruanda 1994}

Ruanda 'da 1994 yılında kurulan güvenli bölge, Fransız-Senegal askeri koalisyonunun kontrolünde BM Güvenlik Konseyi kararının oluşturduğu hukuksal meşruiyet üzerine bina edilmiştir.

\subsubsection{Tarihsel Süreç}

Ocak 1990 da Ruanda' da hükümet kuvvetleriyle, isyanc1 RPF (Rwanda Patriotic Front) birlikleri arasında silahlı çatışmalar başladı. ${ }^{81}$ Üç yıl süren çatışmalardan sonra 09.01.1993 tarihinde dönemin Ruanda Devlet Başkanı ile Tutsilerin idaresinde olan RPF arasında barış anlaşması imzalandı. Bu anlaşmaya göre, çatışmalara son verilecek, bir geçiş hükümeti kurulacak ve barışın denetlenmesi görevi BM Barış Gücü’ne verilecekti. ${ }^{82}$ Bu görevin yerine getirilmesi için BM

80 The Fall of Srebrenica, para. $490 \mathrm{~d}$.

81 Archiv der Gegenwart 1990, s. 34914 A.

82 UN-Doc. S/5126350, 24.8.1993, para. 22; UN-Doc. S/5126488,24.9.1993, para. 8. 
Güvenlik Konseyi S/RES/872 (1993) sayılı kararıla United Nations Assistance Mission for Ruanda (UNAMIR) adı altında bir barış misyonu kurdu. Bu barış gücünün görevleri arasında şu hususlar sayılmıştı: Ateşkesin denetlenmesi, insani yardımların dağıtımının organize edilmesi, sivil halkın yeniden topluma kazandırılması ve korunması ve anlaşmanın uygulanması konularında yardım etmek.

06.04.1994 tarihinde Ruanda ve Burundi Devlet Başkanları'nın şüpheli bir uçak kazasında ölmeleri üzerine Ruanda'da yaşayan Hutu ve Tutsi grupları arasında karşılıklı olarak katliam başladı. Bunun ardından Zaire'ye kitlesel göçler başladı. Belçika'nın, durumun tehlikeli oluşu sebebiyle UNAMIR bünyesinde bulunan silahlı birliklerini geri çekeceğini açıklamasından sonra BM Güvenlik Konseyi, UNAMIR'in içindeki asker sayısını 2800'den 270'e indirmeye karar verdi ${ }^{83}$ Böylece RPF, Hutu ve Tutsi grupları arasındaki çatışmalarda üç ayda $500.000-1.000 .000$ kişinin katledilmesini ve sayısız insanın göçe zorlanmasını durdurabilecek ülkedeki tek güç olarak kalmış oldu.

16.05.1994 tarihinde Ruanda Dışişleri Bakanı’nın, Devlet Başkanı’nın bir suikast sonucunda öldürüldüğünü ve bunun RPF tarafindan organize edildiğini Güvenlik Konseyi'nde dile getirmesinden sonra Güvenlik Konseyi, krize ilişkin çekimser tavrından vazgeçerek S/RES/918 (1994) sayılı kararı aldı. Konsey, kararında BM Sözleşmesi'nin VII. Bölümüne dayanarak UNAMIR'in sivil halkın korunması ve insani yardımın yapılması konusundaki yetkilerini artırdı ve asker sayısını 5500'e çıkardı. Konsey, bu kararla aynı zamanda UNAMIR'e bir önlem olarak güvenli bölge (Secure Humanitarian Areas) kurma yetkisi verdi. ${ }^{84} \mathrm{Bu}$ yetki genişlemesine hem Ruanda hükümeti ve hem de RPF razı oldular. ${ }^{85}$

31.05.1994 tarihli BM Genel Sekreteri'nin raporuna göre hükümet birliklerinin kontrolünde olan bölgelerde sistematik katliamlar yap 1 ld $1 .{ }^{86}$ Ayrıca bu raporda 250.000-500.000 kişinin öldürüldüğü ve yaklaşık 1,5 milyon insanın yerlerinden çıkartıldığg belirtilmekteydi. Rapora göre Ruanda'daki olaylar açıç̧a bir soyk1rım suçunun unsurlarını taşıyordu.

Üye devletlerin gerekli silahlı birliği oluşturamaması sebebiyle Güvenlik Konseyi, S/RES/929 say1l kararla 22.06.1994 tarihinde üye devletleri, UNAMIR'in operasyonunun insani hedeflerinin gerçekleşmesi için gerekli bütün ön-

83 UN-Doc S/RES/912 (1994).

84 UN-Doc S/RES/918 (1994) ... 3. Decides to expand UNAMIR's mandate Call to contribute to the security and protection of displaced persons, refugees and civilians at risk in Rwanda, including through the establishment and maintenance, where feasible, of secure humanitarian areas; To provide security and support for the distribution of relief supplies and humanitarian relief operations; 5. Authorizes in this context an expansion of the UNAMIR force level up to 5,500 troops;

85 S/PV.3481. Ruanda hükümeti sadece Kararın ilk bölümünü kabul etti; Fink, Friedenssicherung II, 786. 
lemleri almaları yönünde yetkilendirdi. ${ }^{87}$ Bu kararda Konsey, S/RES/925 (1994) sayılı kararında UNAMIR'e verilen sivil halkın korunması için güvenli bölgenin oluşturulması yetkisinin ${ }^{88}$ yanı sıra ayrıca üye devletlere askeri koalisyon için somut önlem almaları yönünde yetki veriyordu. ${ }^{89} \mathrm{RPF}$ kriz bölgelerine BM Barış Gücü gönderilmesine prensip olarak karşı olmamakla birlikte Fransa'nın bu birliğe katılmasına karşı çıkıyordu..$^{90}$

Bu karardan bir gün sonra S/RES/929 sayılı karara dayanarak 2500 kişilik Fransız askeri, "Operation Turquoise" kapsamında RPF kontrolündeki Ruanda'nın 1/5'lik bir alanına denk gelen Güneybatı bölgesine girdi ve bu yerde güvenli bölge oluşturdu. ${ }^{91}$ Göçe zorlanan siviller için bu bölgede 10 adet kamp kuruldu. Bu kamp yerlerinde sivil yardım organizasyonlarına yardım faaliyetlerin rahatça yürütmeleri için zemin hazırlandı. Yaklaşık 2 milyon Hutu bu güvenli bölgelere kaçtı. 21.08.1994 tarihinde Fransız askerleri görevi UNAMIR birliklerine devretti. ${ }^{92}$

\subsubsection{Güvenli Bölgesin Güvenliğinin Sağlanması ve İnsani Standart}

Güvenli bölge oluşturulmasının hedefleri arasında insani yardım organizasyonlarının çalışmalarının kolaylaştırılması, insanların yerinde korunması, böylelikle bölgede insani durumun iyileştirilmesi, ayrıca ağır insan hakları ihlallerinin sonlandırılması ve bu sayede Zaire'ye olan kitlesel göçlerin sona erdirilmesi amaçları sayılabilir. ${ }^{93}$

Güvenlik Konseyi'nin S/RES/929 (1994) sayılı kararı üye devletlere "bütün gerekli yöntemleri” kullanarak S/RES/925 (1994) sayılı kararda yer alan insani amaçları gerçekleştirmek için operasyon yapma yetkisi veriyordu. Bu karardan hemen sonra bir askeri koalisyon oluşturuldu. Askeri koalisyon tarafından güvenli bölgeler tesis edilerek bu bölgelerin sınırları çatışan taraflara bildirildi. Çatışan taraflar bu bölgelerin boşaltılması sırasında kayda değer bir mukavemet göstermedi.

19.07.1994 tarihinde RPF, ilan edilen güvenli bölgenin haricinde neredeyse ülkenin bütününde kontrolü ele geçirdikten sonra başkent Kigali'de birlik hükümeti kurdu ve tek taraflı ateşkes ilan etti. 21.08.1994 tarihinde Operation

87 UN-Doc S/RES/929 (1994).

88 UN-Doc S/RES/925 (1994), para. 4/a.

89 UN-Doc S/RES/925 (1994) para. 4. Decides that the Mission of Member States will be limited to a period of two months unless the Secretary-General determines at an earlier date that the expanded UNAMIR is able to carry out its mandate ... .",

90 BM Genelsekreterinin 03.08.1994 tarihli raporu, UN-Doc. S/1994/924/ 3 Ağustos 1994.

91 Archiv der Gegenwart (1994) s.39048 A

92 Archiv der Gegenwart (1994) s.39239, A

93 Simon, s. 35.. 
Turquoise görevini tamamladı ve tarafların da rızasıyla 5500 kişilik UNAMIR II güvenli bölgede insani yardım görevini üstlendi. ${ }^{94} \mathrm{Bu}$ arada özellikle Zaire'deki mülteci kamplarında insani durum endişe verici bir hale gelmişti. ${ }^{95}$

UNAMIR II ağırlıklı olarak sayıları yaklaşık 750.000'i bulan sığınmacıların geri dönüşlerini organize etmek için faaliyet gösterdi. Daha sonra Güvenlik Konseyi'nin S/RES/965 (1994) sayılı kararıyla bu birliğin sayısı 6000'e çıartıldı.

Güvenli bölgelerin isyancıların sığınağı, soykırım suçlularının kaçma yeri ya da Zaire'ye kaçma yolu olması, silah deposu olarak kullanılması gibi bilgiler RPF'de özellikle güvenli bölge üzerinde hakimiyeti kaybetme ve ülkesel bütünlük korkusu oluşturdu. Mülteci kamplarında sürekli çatışmaların baş göstermesi ve iç güvenlik için tehlikeli bir hal almaya başlaması sebebiyle UNAMIR II RPF'nin de desteğiyle 1994'te "Operation Hope" adı altında bir operasyon başlatt1. Bu operasyonun hedefi mülteci kamplarını silahlardan arındırmaktı. Bu operasyona rağmen kamplarda gerilim ve krizlerin sürmesi sebebiyle Ruanda geçici hükümeti 1995 Şubat ayında mültecilerin güvenliği için ve evlerine dönüşleri için kampları tamamen kapatma kararı ald1.${ }^{96} 17.04 .1995$ 'te UNAMIR II'nin de katıldığı bir operasyonla Kibeho kamplarının zorla kapatılması sonucunda kitlesel göç başladı. Bu boşaltma sırasında çıkan çatışmalarda 2000'in üstünde koruma altındaki sivil ve insani yardım organizasyonu çalışanları 100 kişilik UNAMIR II birliğinin gözleri önünde hayatlarını kaybetti. Hâlbuki S/RES/918 (1994) say1lı karara göre UNAMIR II'nin insani yardım personelini, sivil halkı ve güvenli bölgeyi koruma kapsamında kuvvet kullanma yetkisi vard $1 .{ }^{97}$ Bunun haricinde Güneybatı Ruanda'da bulunan diğer kampların boşaltılması üç hafta içinde herhangi bir olay olmadan sonlandırılabildi. Mülteciler ya evlerine döndüler ya da Zaire'ye kaçtılar.

Genel olarak ülke içinde yerlerinden edilen sivillerin geri dönüşleri yeni saldırılardan korku ve kamplardaki insani yardımdan yararlanmaları sebebiyle gayet yavaş yürüdü. Bununla birlikte Ruanda'daki Operation Turquoise askeri koalisyon güvenli bölgede sivillerin korunması açısından özellikle siviller arasında katliamı önlediği için başarılı sayılabilir. ${ }^{98}$ Ruanda kamplarında genel insani ihtiyaçlar gerek Operation Turquoise ve gerekse sonradan UNAMIR II tarafindan karş1lanabilmişti. Özellikle güvenli bölge uygulamasıyla Zaire'deki birçok mül-

94 S/PV.3481, 15.12.1994, 3.

95 UNSG-Report, PRST/1994/59, UN-Doc. S/1994/1308, 18.11.1994.

96 Simon, s. 36.

97 UN-Doc- S/RES/918(1994) para. 4: "Recognizes that UNAMIR may be required to take action in selfdefence against persons or groups who threaten protected sites and populations, United Nations and other humanitarian personnel or the means of delivery and distribution of humanitarian relief; ( ... )", Bkz. UNHCR, The State of the World's Refugees, 1995, 128. 
teci kampında insani olmayan şartlarda yaşayan sivil kurtulabilmiştir. Ruanda'da taraflar arasında çatışmaların sürüyor olması, Hutulardan korku, zaman zaman Zaire hükümetinin sınır kapılarını kapatması, kampların coğrafik koşulları gibi nedenler mültecilerine komşu ülkelere kaçışını imkânsızlaştırıyordu. ${ }^{99}$

Ruanda'da oluşturulan güvenli bölge devam etmekte olan iç savaş sebebiyle ağır insan hakları ihlallerini ve sivillerin hayatlarını kaybetmelerini önlemede çok başarılı olamadı. 


\section{Sonuç}

Yukarıda ele alınan Güvenlik Konseyi uygulamalarından hareketle güvenli bölgenin, takip altındaki sivil halkın korunması, insani yardımların muhtaçlara ulaştırılması ve sığınmacı akımının durdurulması ve sonuç olarak barış görüşmelerine zemin hazırlanması amacıyla silahlardan ve askerlerden arındırılmış, kendisine saldırı yapılmayan bölgeler olarak tasarlandığı görülmektedir.

BM çevrelerinde güvenli bölge uygulamaları öncelikle insanlığa karşı suçlar, soykırım suçu ve kitlelerin takip edilmesi kapsamında savaş suçları için düşünülmüştü. Ve bu uygulamalar ya BM Sözleşmesi'nin VII. Bölümü çerçevesinde BM Güvenlik Konseyi'nde alınan kararlara dayandırılmış ya da bu bölgeler kuvvet kullanarak ele geçirilerek oluşturulmuştu. Güvenli bölgelerin askerden ve silahtan arındırılmasının ve silah gücüyle korunmasının vazgeçilmez bir gereklilik olduğu tecrübe edilmiştir. Yetki olmasına rağmen güvenli bölgeye yönelik saldırılara silahlı karşılık verilmemesi sebebiyle güvenli bölge konsepti büyük zarar gördü. Ayrıca sivillere bu yolla büyük zararlar verildi. Özellikle Srebrenica güvenlik bölge uygulaması, ardında büyük bir acı bırakmıştır. Srebrenica örneği gerçek anlamda bir güvenli bölgenin hedeflerine ulaşmasının güvenli bölgenin güvenliğinin ne pahasına olursa olsun sağlanmasına bağlı olduğunu göstermiştir. Aksi takdirde güvenli bölgeler tam aksine siviller için bir tuzak fonksiyonu görecektir.

Sonuç olarak her ne kadar güvenli bölge, BM sistemi içinde uluslararası insancıl hukuk için faydalı ve etkili bir konsept olarak kabul edilse de güvenlik sorununu halletmeden bu tedbire başvurulmaması gerekliliği tecrübe edilmiştir. 


\section{Kaynakça}

Demirel, Naim, BM Güvenlik Konseyi ve Uluslararası Barışın Korunması, İstanbul 2015.

Endemann, Harald, Kollektive Zwangsmassnahmen zur Durchsetzung humanitarer Normen, ein Beitrag zum Recht der humanitaren Intervention, 1997.

Fink, Udo, Kollektive Friedenssicherung II, Frankfurt, Kapitel VII UN-Charta in der Praxis des Sicherheitsrats der Vereinten Nationen, 1999.

Freedman, Lanwrence, Boren, David, "Safe Havens" for Kurds in Post-War Iraq in: To Louose, ed. Nigel S. Rodley, London, the Bands of Wickedness: International Intervention in Defence of Human Rights, 1992.

Gading, Heike, Der Schutz grundlegender Menschenrechte durch militarische Massnahmen des Sicherheitsrates - das Ende staatlicher Souveranitat, Berlin, 1996.

Giersch, Carsten, Konfliktregulierung in Jugoslawien, Konfliktregulierung in Jugoslawien 1991-1995: Die Rolle von OSZE, EU, UNO und NATO, Baden-Baden, 1998.

Herbst, Jochen, Rechtskontrolle des UN-Sicherheitsrates, Frankfurt-Berlin, 1999.

Hottinger, Arnold, Die arabische Welt nach dem Golfkrieg, in: EA 46, 1991.

Landgren, Karin, "Safety Zones and International Protection: A Dark Grey Area", International Journal of Refugee Law, 7 (3).

Leurdijk, Dick, A., "Background Paper: United Nations Protected Force (UNPROFOR)", Humanitarian Action and Peace Keeping Operations, 1997.

Lupis, Ivan, "Human rights abuses in the wake of the collapse of the United Nations-designated 'safe area' of Srebrenica and the international community", Helsinki Monitor, 1, 1996.

Malanczuk, "The Kurdish Crisis and Allied Intervention in the Aftermath of the Second Gulf War", European Journal of International Law, 2, 1991.

Ogata, Sadako, "UNHCR in the Balkans, humanitarian Action in the Midst of War", UN Peacekeeping in Trouble: Lessons Learned from the Former Yugoslavia, 1998.

Simon, Annette, UN-Schutzzonen - ein Schutzinstrument für verfolgte Personen, Berlin- Heidelberg, 2010.

"Vandenberghe, Brecht, Der Fall der UN "Safe Area" Srebrenica und die Rolle des niederlaendischen Bataillons Dutchbalt eine Zusammenfassung der niederlaendischen Untersuchengen”, ZaöRV, 61, 2001. 
Tiso, Christoper.M., "Safe Haven Refugee Programs: A Method of Combating International Refugee Crises", Georgetown Immigration Law Journal, 8, 1994.

Weller, M. (ed.), "Peace-Keeping and Peace-Enforcement in the Republic of Bosnia and Herzegovina", ZaöRV, 56, 1996. 